\title{
The Long Run Determinants of the U.S. Trade Balance: A Reexamination Using Bi \& Multivariate Cointegration Approach
}

\author{
Amarendra Sharma \\ Dept. of Economics, Elmira College \\ One Park Place, Elmira, NY 14901, USA \\ Tel: 1-607-735-1923_E-mail: asharma@elmira.edu
}

Received: December 20, 2011 Accepted: February 29, 2012 Published: March 17, 2012

doi:10.5296/rae.v4i1.1171 URL: http://dx.doi.org/10.5296/rae.v4i1.1171

\begin{abstract}
This paper extends our understanding of the long-run determinants of the U.S. current account and trade balances. Earlier studies have recognized the long-run effects of fiscal, monetary, and commercial policy variables on the external account balances. But none of them reported the interest rate measures to be cointegrated with the external account balances. This study provides strong evidence to suggest that the various interest rate measures are also the long-run determinants of the U.S. current account and trade balances.
\end{abstract}

Keywords: Trade Deficit, Current Account, Fiscal Policy, Monetary Policy, Commercial Policy, Interest Rate 


\section{Introduction}

The primary objective of this paper is to reexamine the long-run determinants of the U.S. trade balance. This particular issue assumes added significance due the fact that the U.S. has been running trade deficit for the most part of the last four decades in spite of changes in the fiscal, monetary, and commercial policies over the years to deal with it, directly or indirectly. It is not unusual for the politicians to put the blame of the economic problems facing the country squarely on the twin deficits of internal and external accounts. It is hoped that a better understanding of the long-run determinants will allow the policy makers to use the policy tools at their disposal in a more targeted and sustained fashion to deal with the issue of current account deficits.

The studies that have been carried out so far to understand the long-run relationships among the policy tools measures and the external account balances are inadequate in the sense that they either do not apply the recent advances in time series econometrics on cointegration and unit root analysis (earlier studies rely on the structural models or reduced form models that do not take stationarity of the time series involved into account (see for example, Magee, 1973; Krugman \& Baldwin, 1987; Rosensweig \& Koch, 1988; Darrrat, 1988, Miller \& Russek, 1989; Bahmani-Oskooee, 1989), or are marred by the relatively small time horizons (see for example Alse \& Bahmani-Oskooee, 1992; Bahmani-Oskooee, 1992, 1995; Kim, 1995). One study that stands out in terms of its modern approach to this topic is by Bahmani-Oskooee (92), who investigates this issue by looking at the quarterly data collected from various sources for the time period 1971:1-1988:4, a total of eighteen years. Based on this sample he concludes that the full employment budget deficit and to some extent the money supply as measured by M2 are the only two possible long-run determinants of the U.S. trade balance. His analysis relies on examining the stationarity of the individual time series and bilateral cointegration a la Engle \& Granger (1987). Kim (1995) in a follow-up to this paper, which essentially draws attention to the inadequacies of the techniques used, comes up with a conclusion that the money supply as measured by M2, the terms of trade, and the nominal effective exchange rate, are all cointegrated with the trade and current account balances, and therefore, have the equilibrium (long-run) relationships. His study does not support the full employment budget deficit as one of the long run determinants of the U.S. trade balance, as he does not find the trade balance to be cointegrated with the full employment budget.

In this paper, I revisit the issue and look at the quarterly data from 1974:1-2007:4. My sample includes current government expenditure and receipts as the measures of fiscal policy stance, and not the full employment budget deficit used by Bahmani-Oskooee $(1992,1995)$ and Kim (1995). Based on my analysis, I confirm that on the fiscal policy side only the government's current expenditure and on the monetary policy side only the M2 measure of money are cointegrated with the balance of trade and the current account balance in a bivariate setting. But when I consider the multivariate cointegration settings then the government's current expenditure, receipts, and net savings, M1 \& M2 measures of money stock, the treasury bill rate, the interest rates on the medium and long term government bonds, the terms of trade, and the nominal effective exchange rate are all found to have at least one cointegarting vector with the external account balances, thereby confirming the existence of the long-run 
relationships among them. Earlier studies, it appears deliberately excluded interest rate measures from the analysis on the grounds that the federal reserve bank's monetary policy can be represented by either the interest rate or the measures of money supply. But as is well known that a change in money supply does not automatically result in a change in interest rate especially if the financial institutions do not have enough confidence in the borrower's ability to repay the loan and they just sit on the excess reserves as was the case in the recent financial crisis. Clearly, we cannot simply assume that monetary aggregates alone are sufficient to capture the long run relationship between the current account balance and monetary policy. The direction of flow is like this: An increase in M1 or M2 will decrease the interest rate (which may or may not happen), which in turn will stimulate domestic spending and investment causing GDP to rise and net exports to decrease. On the other hand, a fall in the interest rate will result in a flight of funds in the foreign exchange market causing the dollar to depreciate and the net exports to improve in turn. This study lends credence to the earlier findings of Bahmani-Oskooee $(1992,1995)$ and Kim (1995), and extends the long run determinants to include the interest rate variables, which was not mentioned as statistically significant by the earlier studies.

\section{Data}

This study uses quarterly data from 1974:1-2007:4. The data is collected from various sources including the publications from the Bureau of Economic Analysis (BEA), the International Financial Statistics (IFS), and the Bank for International Settlements (BIS). The variables BOT (real balance of trade on goods and services) and BCA (real balance on the current account) represent the two measures of the U.S. external account balance. The fiscal policy measures are represented by GEXP (real seasonally adjusted government current expenditure), GRECPT (real seasonally adjusted government current receipts), and GNS (real seasonally adjusted net government savings), respectively. The variables M1 \& M2 (real seasonally adjusted money stock as measured by M1 \& M2) represent the monetary policy measures. The commercial policy measures are represented by the variables TOT (real terms of trade) and NEX (nominal effective exchange rate). I also have three measures of interest rate, namely, TB (real Treasury bill rate), GBMT (real interest rate on the medium-term government bond), and GBLT (real interest rate on the long-term government bond). The variable GNP (real seasonally adjusted gross national product) measures the overall economic activity. This study uses the GNP deflator with 2005 as the base year.

\section{Methodology}

Following the prescription of Engle \& Granger (1987) I tested all thirteen time series for unit root. This issue is considered important because the standard econometric methodologies assume stationarity of the underlying time series. If the time series is not stationary, which is the case for many of them; the inferences based on the usual statistical tests become meaningless. For example, the ordinary least squares (OLS) estimation that uses the non-stationary time series, results in a spurious regression, unless these time series are cointegrated (Granger \& Newbold, 1974). Due to the generally low power of unit root tests, I decided to perform three different unit root tests: the Augmented Dickey-Fuller test (ADF), 


\section{Macrothink}

The Dickey-Fuller Generalized Least Squares test (DFGLS), and the Phillips-Perron test (PP). I do not perform the simple Dickey-Fuller test because it is valid only when the series is generated by a first-order autoregressive process. The ADF test, on the other hand, makes a parametric correction for higher-order autocorrelation by including the lagged differences of the regressand as the regressors. The ADF test is based on estimating the following regression:

$$
y_{t}=\beta^{\prime} M_{t}+\phi y_{t-1}+\sum_{j=1}^{p} \psi_{j} \Delta y_{t-j}+\varepsilon_{t}
$$

where $M_{t}$ is a vector of deterministic terms (constant, trend, etc.). The $p$ lagged difference terms, $\Delta y_{t-j}$, are used to approximate the ARMA structure of the errors, and the value of $p$ is set such that the error $\varepsilon_{t}$ is serially uncorrelated. The error term is also assumed to be homoskedastic.

The DFGLS test is a simple modification of the ADF test in which the data is detrended.

The test regression for the DFGLS test is:

$$
\Delta y_{t}^{d}=\pi y_{t-1}^{d}+\sum_{j=1}^{p} \psi_{j} \Delta y_{t-j}^{d}+\varepsilon_{t}
$$

where $y_{t}^{d}$ is the detrended data. It has been shown that the DFGLS test has a higher power than the DF tests.

The Phillips-Perron (PP) unit root test differs from the ADF test primarily in terms of its treatment of error specific serial correlation and heteroskedasticity. In particular, the PP test ignores any serial correlation in the test regression, whereas the ADF test tries to mimic the ARMA structure of the error terms through parametric autoregression,

The test regression for the PP test is:

$$
\Delta y_{t}=\beta^{\prime} M_{t}+\pi y_{t-1}+u_{t}
$$

where $u_{t}$ is $I(0)$ and may be heteroskedastic. The PP test corrects for any serial correlation and heteroskedasticity in the error $u_{t}$ by directly modifying the test statistics. One advantage of the PP test over the ADF test is that it is robust to general forms of heteroskedasticity in the error term $u_{t}$. Additionally, the user does not have to specify the lag length for the test regression. 


\section{Mll Macrothink}

I performed these three tests on all thirteen variables in levels and their first differences. These tests raise two practical problems. The first involves the choice of exogenous variable in the regression (a constant and a linear time trend, drift, and none). For the ADF test I report the regression results for the cases with a linear time trend and the ones with a drift. For the DFGLS test I report the results for two cases: (a) the series is stationary around a mean, and (b) the series is stationary around a linear time trend. For the PP test I report the results from cases where a trend is included and the ones without it. The second practical problem arises due to the choice of the lag length in the regression. That is the number of the lagged differences to be added as regressors. Following Kim (95) I use four lags of the differences in the regressions for the ADF test as the data is quarterly. For the DFGLS tests I use the optimal lag generated by the $\mathrm{Ng}$-Perron sequential-T method.

It is well documented in the literature that most macro variables are non-stationary in their levels but stationary in their first-differences. If individual time series turn out to be non-stationary in their levels, that is, contain stochastic trend, it is still possible that these stochastic trends are common across the series, leading to one or more stationary combinations of the level series. The existence of a long-run equilibrium (stationary) relationship among economic variables is referred to as cointegration. To find out if the variables are cointegrated, I perform two maximum likelihood tests, the trace and maximum eigenvalue tests of Johansen (1988) and Johansen and Juselius (1990). The first test tests the null hypothesis of at most $r$ cointegrating vectors against the alternative hypothesis of more than $r$ cointegrating vectors. The second test tests the null hypothesis of exactly $r$ cointegrating vectors against the alternative hypothesis of $r+1$ cointegrating vectors. I first report the estimates from the bivariate cases which are followed by the multivariate cases. The maximum lag length for these two tests was set at eight lags. For brevity, I report only the results from the models containing linear trends in the cointegrating regressions for 2, 4, 6, and 8 lags, respectively.

\section{Results}

A preliminary look at the time series plots (see figure 1) suggests that TOT, M1, and GNS are potentially stationary in the levels. However, the three unit root tests do not provide irrefutable evidence of stationarity in the levels for any series. There is some evidence that GNS, GBMT, TOT, and M1 are $I(0)$. Since there is no clinching evidence in favor of these variables being $I(0)$, I err on the side of caution and conclude that all the variables used in this study are $I(1)$. The three tests strongly suggest that all variables become stationary after first differencing (See tables 1, 2, and 3). 

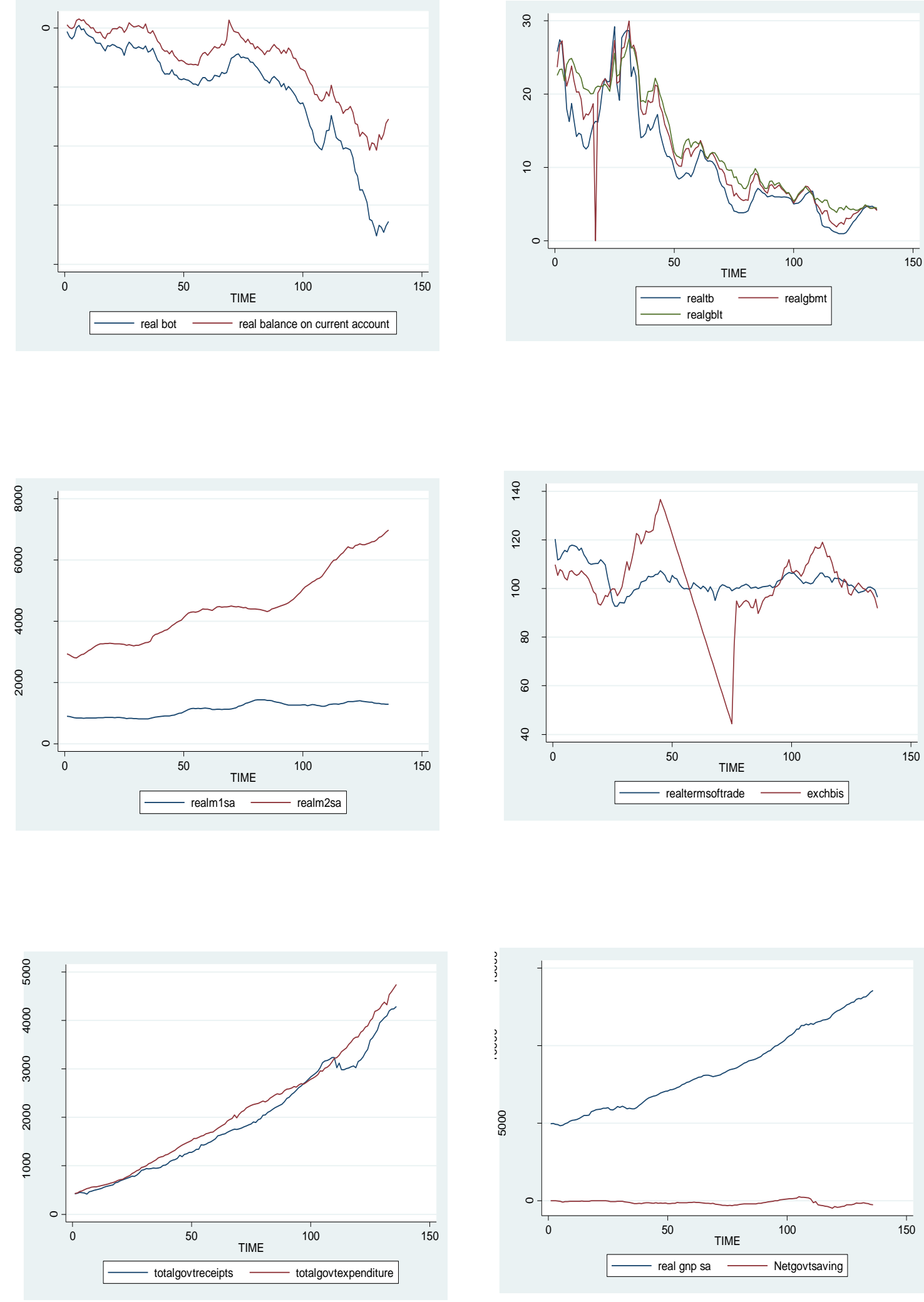

Figure 1: Time series plots 
Table 1: Augmented Dickey Fuller Unit Root Test Results

\begin{tabular}{lllll}
\hline Variable & $(1)$ & $(2)$ & $(3)$ & $(4)$ \\
\hline BOT & 0.441 & -1.044 & $-4.883 * * *$ & $-5.059 * * *$ \\
BCA & -0.942 & -1.996 & $-4.344 * * *$ & $-4.224 * * *$ \\
TB & -1.384 & -2.447 & $-4.054 * * *$ & $-3.968 * * *$ \\
GBMT & -1.366 & -2.438 & $-5.753 * * *$ & $-5.741^{* * *}$ \\
GBLT & -1.258 & -2.454 & $-5.925 * * *$ & $-5.936 * * *$ \\
NEX & -1.912 & -1.287 & $-4.413 * * *$ & $-4.389 * * *$ \\
TOT & $-2.993 * *$ & -3.054 & $-5.501 * * *$ & $-5.495 * * *$ \\
M1 & $-1.575 *$ & -2.018 & $-3.022^{* * *}$ & -3.064 \\
M2 & 0.665 & -1.032 & $-2.487 * * *$ & -2.703 \\
GNP & 1.915 & -0.714 & $-4.292 * * *$ & $-4.832 * * *$ \\
GEXP & 3.461 & 2.409 & -1.651 & $-3.441^{* *}$ \\
GRECPT & 0.866 & -2.242 & $-3.000^{* * *}$ & $-3.158 *$ \\
GNS & $-3.298 * *$ & $-3.607 * *$ & -3.299 & $-3.268 *$ \\
N & 131 & 131 & 130 & 130 \\
\hline
\end{tabular}

Column1 presents the ADF with drift $\mathrm{z}(\mathrm{t})$ test statistics for the variables in levels. Column2 presents the $\mathrm{ADF}$ with trend $\mathrm{z}(\mathrm{t})$ test statistics for the variables in levels. Column 3 presents the ADF with drift $z(t)$ test statistics for the variables in first differences. Column 4 presents the ADF with trend $\mathrm{z}(\mathrm{t})$ test statistics for the variables in first differences.

*** denotes significance at the $1 \%$ level according to MacKinnon's approximate p-value for $\mathrm{z}(\mathrm{t})$ statistics.

** denotes significance at the 5\% level according to MacKinnon's approximate p-value for $\mathrm{z}(\mathrm{t})$ statistics.

* denotes significance at the $10 \%$ level according to MacKinnon's approximate p-value for $\mathrm{z}(\mathrm{t})$ statistics. 
Table 2: Dickey Fuller Generalized Least Squares Unit Root Test Results

\begin{tabular}{lllll}
\hline Variable & $(1)$ & $(2)$ & $(3)$ & $(4)$ \\
\hline BOT & $-1.398(3)$ & $2.374(1)$ & $-4.127(3)^{* * *}$ & $-3.800(2)^{* * *}$ \\
BCA & $-1.858(3)$ & $-0.134(3)$ & $-4.647(2)^{* * *}$ & $-4.233(2)^{* * *}$ \\
TB & $-2.528(3)$ & $-0.226(3)$ & $-3.615(4)^{* * *}$ & $-2.404(4)^{* *}$ \\
GBMT & $-3.154(1)^{* *}$ & $-0.187(2)$ & $-3.179(4)^{* * *}$ & $-1.723(4)^{*}$ \\
GBLT & $-2.676(3)$ & $0.116(1)$ & $-4.501(2)^{* * *}$ & $-3.295(2)^{* * *}$ \\
NEX & $-0.913(3)$ & $0.796(3)$ & $-2.015(3)$ & $-0.841(3)$ \\
TOT & $-1.646(1)$ & $-0.199(1)$ & $-1.968(2)$ & $-0.968(2)$ \\
M1 & $-2.347(3)$ & $-0.679(2)$ & $-3.505(1)^{* * *}$ & $-2.452(2)^{* *}$ \\
M2 & $-1.278(3)$ & $1.549(3)$ & $-2.427(4)$ & $-1.049(4)$ \\
GNP & $-0.438(2)$ & $2.800(2)$ & $-5.544(1)^{* * *}$ & $-3.732(1)^{* * *}$ \\
GEXP & $0.145(4)$ & $2.468(4)$ & $-3.525(3)^{* * *}$ & $-0.968(3)$ \\
GRECPT & $-1.552(3)$ & $1.854(3)$ & $-4.032(2)^{* * *}$ & $-3.466(2)^{* * *}$ \\
GNS & $-3.471(3)^{* *}$ & $-2.501(3)^{* *}$ & $-3.678(2)^{* * *}$ & $-3.657(2)^{* * *}$ \\
N & 131 & 131 & 130 & 130 \\
\hline & & & & \\
\hline
\end{tabular}

Column1 reports the $m u$ statistics for the DFGLS test for the series being stationary around a mean. The variables are in the levels. Column2 reports the $m u$ statistics for the DFGLS test for the series being stationary around a linear time trend. The variables are in the levels. Column3 reports the $m u$ statistics for the DFGLS test for the series being stationary around a mean. The variables are in the first differences. Column 4 reports the $m u$ statistics for the DFGLS test for the series being stationary around a linear time trend. The variables are in the first differences.

The figures in the parentheses are the optimum lag ( $\mathrm{Ng}$-Perron seq $\mathrm{t})$.

*** denotes the significance at the $1 \%$ level according to Elliot, Rothenberg, and Stock (1996) interpolated critical values.

** denotes the significance at the 5\% level according to Elliot, Rothenberg, and Stock (1996) interpolated critical values.

* denotes the significance at the $10 \%$ level according to Elliot, Rothenberg, and Stock (1996) interpolated critical values. 
Table 3: Phillips Perron Unit Root Test Results

\begin{tabular}{lllll}
\hline Variable & $(1)$ & $(2)$ & $(3)$ & $(4)$ \\
\hline BOT & 1.244 & -0.700 & $-9.527 * * *$ & $-9.754 * * *$ \\
BCA & -0.332 & -1.735 & $-11.977 * * *$ & $-11.983 * * *$ \\
TB & -2.040 & -2.700 & $-9.642 * * *$ & $-9.671 * * *$ \\
GBMT & -1.763 & $-4.481 * * *$ & $-18.184 * * *$ & $-18.182 * * *$ \\
GBLT & -0.938 & -2.443 & $-9.651 * * *$ & $-9.620 * * *$ \\
NEX & -1.886 & -1.897 & $-7.913 * * *$ & $-7.882 * * *$ \\
TOT & $-3.098 * *$ & -3.061 & $-10.162 * * *$ & $-10.069 * * *$ \\
M1 & -0.907 & -1.385 & $-5.176 * * *$ & $-5.170 * * *$ \\
M2 & 1.970 & -0.721 & $-5.589 * * *$ & $-5.932 * * *$ \\
GNP & 2.867 & -1.314 & $-8.979 * * *$ & $-9.699 * * *$ \\
GEXP & 6.511 & 3.340 & $-12.323 * * *$ & $-14.510 * * *$ \\
GRECPT & 2.510 & -0.763 & $-11.334 * * *$ & $-11.991 * * *$ \\
GNS & -2.128 & -2.233 & $-12.128 * * *$ & $-12.094 * * *$ \\
\hline
\end{tabular}

Column1 reports the $\mathrm{z}(\mathrm{t})$ statistics from the PP test in levels without including the trend. Column 2 reports the $\mathrm{z}(\mathrm{t})$ statistics from the PP test in levels with trend. Column 3 reports the $\mathrm{z}(\mathrm{t})$ statistics from the PP test in the first differences without including the trend. Column 4 reports the $\mathrm{z}(\mathrm{t})$ statistics from the PP test in the first differences with trend.

*** denotes significance at the $1 \%$ level according to MacKinnon's approximate p-value for $\mathrm{z}(\mathrm{t})$ statistics.

** denotes significance at the 5\% level according to MacKinnon's approximate p-value for $\mathrm{z}(\mathrm{t})$ statistics.

* denotes significance at the $10 \%$ level according to MacKinnon's approximate p-value for $\mathrm{z}(\mathrm{t})$ statistics.

I report the estimates from the bivariate cointegration tests in tables 4 and 5. According to the bivariate cointegration tests based on the trace and maximum eigenvalue statistics, the U.S. balance of trade is cointegrated with the treasury bill rate (6 lags), M2 measure of money supply (4 \& 8 lags), government expenditure (2, 4, 6, \& 8 lags), and net government savings (6 \& 8 lags). Whereas, the real balance on current account is cointegrated with the treasury bill rate (6 lags), nominal effective exchange rate ( $6 \& 8$ lags), the real terms of trade $(6 \& 8$ lags), M1 measure of money supply ( $6 \& 8$ lags), M2 measure of money supply $(4,6, \& 8$ lags), government expenditure ( $2 \& 8$ lags), and net government savings (6 lags). Following 
Kim (1995), when I consider a trivariate cointegration setting, the results of which are presented in tables 6 and 7, the balance of trade and real GNP are found to be cointegrated with the terms of trade (6 lags), M2 measure of money supply (8 lags), government expenditure ( 8 lags), and government receipts ( 8 lags). Whereas, the balance on current account and real GNP are cointegrated only with the M2 measure of money supply (8 lags) and government expenditure (2, 8 lags). In an extended version of the cointegration model $a$ la Bahmani-Oskooee (1995), the results of which are presented in tables 8 and 9, where I add the M2 measure of money supply along with the real GNP, I find that the real terms of trade (6, 8 lags), the nominal effective exchange rate (2, 8 lags), government expenditure $(2,4,6,8$ lags), government receipts (2, 6, 8 lags), treasury bill rate (6, 8 lags), GBMT (6, 8 lags), and GBLT (4, 6, 8 lags) are all cointegrated. Whereas, in a similar setting with BOT replaced with the balance on current account, I find evidence to support the cointegration hypothesis for the real terms of trade (6, 8 lags), the nominal effective exchange rate (2, 4, 6, 8 lags), government expenditure (8 lags), government receipts $(2,6,8$ lags), treasury bill rate $(6,8$ lags), GBMT (6, 8 lags), and GBLT (4, 8 lags).

Table 4: Johansen-Juselius Bivariate Cointegration Results (Balance of Trade)

\begin{tabular}{|c|c|c|c|c|c|c|c|c|c|}
\hline Variable & Rank & Trace & Max & Trace & Max & Trace & Max & Trace & Max \\
\hline Lags & & 2 & 2 & 4 & 4 & 6 & 6 & 8 & 8 \\
\hline \multirow[t]{2}{*}{ TB } & 0 & 12.05 & 11.84 & 10.85 & 9.41 & 18.02 & $18.05^{*}$ & 11.74 & 10.93 \\
\hline & 1 & 0.20 & 0.20 & 1.43 & 1.43 & 0.00 & 0.00 & 0.80 & 0.80 \\
\hline \multirow[t]{2}{*}{ GBMT } & 0 & 12.55 & 12.29 & 9.22 & 8.01 & 8.94 & 8.93 & 12.56 & 11.87 \\
\hline & 1 & 0.26 & 0.26 & 1.20 & 1.20 & 0.00 & 0.00 & 0.68 & 0.68 \\
\hline \multirow[t]{2}{*}{ GBLT } & 0 & 9.00 & 8.83 & 16.32 & 15.47 & 7.88 & 7.88 & 8.49 & 8.24 \\
\hline & 1 & 0.17 & 0.17 & 0.84 & 0.84 & 0.00 & 0.00 & 0.24 & 0.24 \\
\hline \multirow[t]{2}{*}{ NEX } & 0 & 9.80 & 7.61 & 12.25 & 7.83 & 14.36 & 12.24 & 9.55 & 6.61 \\
\hline & 1 & 2.19 & 2.19 & 4.41 & 4.41 & 2.12 & 2.12 & 2.93 & 2.93 \\
\hline \multirow[t]{2}{*}{ TOT } & 0 & 9.33 & 7.14 & 12.82 & 9.13 & 15.53 & 12.28 & 15.34 & 11.10 \\
\hline & 1 & 2.18 & 2.18 & 3.68 & 3.68 & 3.25 & 3.25 & 4.23 & 4.23 \\
\hline \multirow[t]{2}{*}{ M1 } & 0 & 8.52 & 8.12 & 14.44 & 13.66 & 18.56 & 18.31 & 17.70 & 15.79 \\
\hline & 1 & 0.40 & 0.40 & 0.78 & 0.78 & 0.25 & 0.25 & 1.91 & 1.91 \\
\hline \multirow[t]{2}{*}{ M2 } & 0 & 10.18 & 10.15 & $19.03^{*}$ & $18.23^{*}$ & 17.40 & 16.56 & $31.19 * *$ & $29.50 * *$ \\
\hline & 1 & 0.03 & 0.03 & 0.79 & 0.79 & 0.84 & 0.84 & 1.68 & 1.68 \\
\hline \multirow[t]{2}{*}{ GNP } & 0 & 6.72 & 5.39 & 5.68 & 5.11 & 5.93 & 4.83 & 8.18 & 5.31 \\
\hline & 1 & 1.32 & 1.32 & 0.56 & 0.56 & 1.09 & 1.09 & 2.87 & 2.87 \\
\hline \multirow[t]{2}{*}{ GEXP } & 0 & $26.23 * *$ & $25.90 * *$ & $22.65^{*}$ & $20.56^{*}$ & $20.22 *$ & $17.98^{*}$ & $19.35^{*}$ & 18.04 \\
\hline & 1 & 0.32 & 0.32 & 2.08 & 2.08 & 2.23 & 2.23 & 1.30 & 1.30 \\
\hline GRECP & 0 & 7.28 & 5.31 & 6.48 & 5.20 & 11.75 & 11.62 & 9.90 & 9.18 \\
\hline $\mathrm{T}$ & 1 & 1.96 & 1.96 & 1.28 & 1.28 & 0.13 & 0.13 & 0.71 & 0.71 \\
\hline \multirow[t]{2}{*}{ GNS } & 0 & 5.82 & 5.81 & 14.23 & 14.23 & $22.93 *$ & $22.88 * *$ & $19.35^{*}$ & $18.77 *$ \\
\hline & 1 & 0.01 & 0.01 & 0.00 & 0.00 & 0.04 & 0.04 & 0.58 & 0.58 \\
\hline
\end{tabular}

** denotes significance at the $1 \%$ level, $*$ denotes significance at the $5 \%$ level 
Table 5: Johansen-Juselius Bivariate Cointegration Results (Balance on Current Account)

\begin{tabular}{|c|c|c|c|c|c|c|c|c|c|}
\hline Variable & Rank & Trace & Max & Trace & Max & Trace & Max & Trace & Max \\
\hline Lags & & 2 & 2 & 4 & 4 & 6 & 6 & 8 & 8 \\
\hline \multirow[t]{2}{*}{ TB } & 0 & 14.67 & 12.20 & 13.61 & 9.62 & $19.61^{*}$ & $17.48^{*}$ & 13.99 & 11.40 \\
\hline & 1 & 2.46 & 2.46 & 3.99 & 3.99 & 2.12 & 2.12 & 2.58 & 2.58 \\
\hline \multirow[t]{2}{*}{ GBMT } & 0 & 13.72 & 11.34 & 13.67 & 10.43 & 11.16 & 9.39 & 15.39 & 12.08 \\
\hline & 1 & 2.38 & 2.38 & 3.24 & 3.24 & 1.77 & 1.77 & 3.30 & 3.30 \\
\hline \multirow[t]{2}{*}{ GBLT } & 0 & 9.74 & 7.81 & 17.38 & 15.05 & 9.48 & 8.53 & 10.30 & 9.38 \\
\hline & 1 & 1.93 & 1.93 & 2.33 & 2.33 & 0.95 & 0.95 & 0.923 & 0.92 \\
\hline \multirow[t]{2}{*}{ NEX } & 0 & 16.47 & 12.20 & 17.36 & 10.54 & $22.86^{*}$ & 15.33 & $18.84^{*}$ & 10.56 \\
\hline & 1 & 4.26 & 4.26 & 6.81 & 6.81 & 7.52 & 7.52 & $8.28 * *$ & $8.28 * *$ \\
\hline \multirow[t]{2}{*}{ TOT } & 0 & 12.08 & 8.89 & 15.95 & 9.77 & $18.50 *$ & 12.06 & $20.79 *$ & 14.11 \\
\hline & 1 & 3.19 & 3.19 & 6.17 & 6.17 & 6.43 & 6.43 & $6.67 * *$ & $6.67 * *$ \\
\hline \multirow[t]{2}{*}{ M1 } & 0 & 8.71 & 7.74 & 16.81 & 15.04 & $20.31^{*}$ & $18.78^{*}$ & $21.68^{*}$ & $18.16^{*}$ \\
\hline & 1 & 0.97 & 0.97 & 1.77 & 1.77 & 1.52 & 1.52 & 3.52 & 3.52 \\
\hline \multirow[t]{2}{*}{ M2 } & 0 & 14.07 & 12.03 & $22.68 *$ & $18.73^{*}$ & $21.12^{*}$ & 15.89 & $32.61 * *$ & $26.22 * *$ \\
\hline & 1 & 2.03 & 2.03 & 3.95 & 3.95 & $5.22 *$ & $5.22 *$ & $6.38^{*}$ & 6.38 \\
\hline \multirow[t]{2}{*}{ GNP } & 0 & 6.29 & 4.19 & 6.87 & 5.59 & 5.98 & 5.01 & 8.91 & 7.44 \\
\hline & 1 & 2.09 & 2.09 & 1.28 & 1.28 & 0.96 & 0.96 & 1.47 & 1.47 \\
\hline \multirow[t]{2}{*}{ GEXP } & 0 & $23.95^{* *}$ & $23.53^{* *}$ & 16.38 & 16.36 & 16.09 & 16.08 & 17.42 & $17.41^{*}$ \\
\hline & 1 & 0.42 & 0.42 & 0.02 & 0.02 & 0.00 & 0.00 & 0.00 & 0.00 \\
\hline GRECP & 0 & 7.55 & 5.84 & 8.05 & 4.45 & 8.59 & 6.38 & 10.44 & 8.56 \\
\hline $\mathrm{T}$ & 1 & 1.71 & 1.71 & 3.60 & 3.60 & 2.20 & 2.20 & 1.87 & 1.87 \\
\hline \multirow[t]{2}{*}{ GNS } & 0 & 6.59 & 4.99 & 16.35 & 13.44 & $22.11^{*}$ & $18.95^{*}$ & 10.44 & 8.56 \\
\hline & 1 & 1.59 & 1.59 & 2.90 & 2.90 & 3.15 & 3.15 & 1.87 & 1.87 \\
\hline
\end{tabular}

** denotes significance at the $1 \%$ level, * denotes significance at the $5 \%$ level 
Table 6: Johansen-Juselius Trivariate Cointegration Results

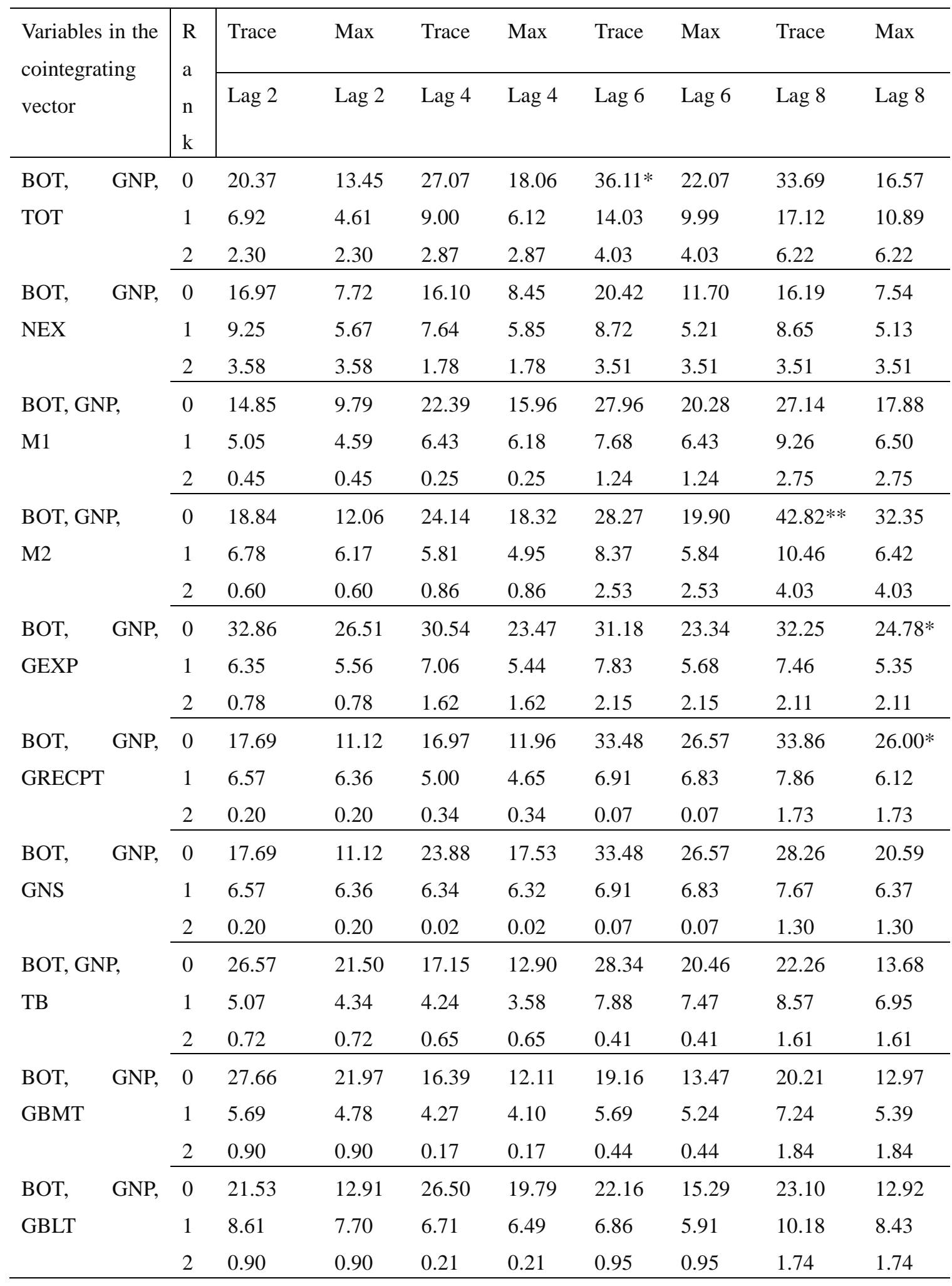

** denotes significance at the $1 \%$ level, * denotes significance at the $5 \%$ level 
Table 7: Johansen-JuseliusTrivariate Cointegration Results

\begin{tabular}{|c|c|c|c|c|c|c|c|c|c|}
\hline \multirow{2}{*}{$\begin{array}{l}\text { Variables in the } \\
\text { cointegrating vector }\end{array}$} & \multirow{2}{*}{$\begin{array}{l}\mathrm{R} \\
\mathrm{a} \\
\mathrm{n} \\
\mathrm{k}\end{array}$} & \multirow{2}{*}{\begin{tabular}{|l} 
Trace \\
Lag 2 \\
\end{tabular}} & \multirow{2}{*}{$\begin{array}{l}\text { Max } \\
\text { Lag } 2\end{array}$} & \multirow{2}{*}{$\begin{array}{l}\text { Trace } \\
\text { Lag } 4\end{array}$} & \multirow{2}{*}{$\begin{array}{l}\text { Max } \\
\text { Lag } 4\end{array}$} & \multirow{2}{*}{$\begin{array}{l}\text { Trace } \\
\text { Lag } 6\end{array}$} & \multirow{2}{*}{$\begin{array}{l}\text { Max } \\
\text { Lag } 6\end{array}$} & \multirow{2}{*}{$\begin{array}{l}\text { Trace } \\
\text { Lag } 8\end{array}$} & \multirow{2}{*}{$\begin{array}{l}\text { Max } \\
\text { Lag } 8\end{array}$} \\
\hline & & & & & & & & & \\
\hline \multirow[t]{3}{*}{ BCA, GNP, TOT } & 0 & 19.63 & 12.01 & 24.24 & 14.15 & 29.59 & 16.47 & 31.59 & 16.05 \\
\hline & 1 & 7.61 & 4.22 & 10.09 & 6.04 & 13.12 & 8.21 & 15.53 & 9.62 \\
\hline & 2 & 3.39 & 3.39 & 4.04 & 4.04 & $4.90^{*}$ & $4.90 *$ & $5.90^{*}$ & $5.90^{*}$ \\
\hline \multirow[t]{3}{*}{ BCA, GNP, NEX } & 0 & 21.39 & 13.30 & 20.39 & 10.84 & 26.17 & 15.01 & 24.42 & 13.72 \\
\hline & 1 & 8.09 & 6.06 & 9.54 & 8.36 & 11.16 & 10.02 & 10.70 & 9.16 \\
\hline & 2 & 2.02 & 2.02 & 1.17 & 1.17 & 1.13 & 1.13 & 1.53 & 1.53 \\
\hline BCA, GNP, & 0 & 17.33 & 10.73 & 23.10 & 16.19 & 29.28 & 22.30 & 28.18 & 20.32 \\
\hline \multirow[t]{2}{*}{ M1 } & 1 & 6.60 & 6.16 & 6.90 & 5.90 & 6.97 & 5.44 & 7.85 & 5.82 \\
\hline & 2 & 0.43 & 0.43 & 1.00 & 1.00 & 1.52 & 1.52 & 2.03 & 2.03 \\
\hline BCA, GNP, & 0 & 20.48 & 15.15 & 22.49 & 17.67 & 28.20 & 19.68 & $40.40^{*}$ & $28.72^{*}$ \\
\hline \multirow[t]{2}{*}{ M2 } & 1 & 5.32 & 3.24 & 4.81 & 4.24 & 8.52 & 6.92 & 11.67 & 9.36 \\
\hline & 2 & 2.08 & 2.08 & 0.57 & 0.57 & 1.60 & 1.60 & 2.31 & 2.31 \\
\hline \multirow[t]{3}{*}{ BCA, GNP, GEXP } & 0 & 29.51 & $24.56^{*}$ & 25.55 & 20.87 & 29.12 & 23.62 & $35.03 *$ & $27.25^{*}$ \\
\hline & 1 & 4.94 & 4.94 & 4.67 & 4.46 & 5.50 & 5.10 & 7.78 & 7.22 \\
\hline & 2 & 0.00 & 0.00 & 0.21 & 0.21 & 0.39 & 0.39 & 0.55 & 0.55 \\
\hline \multirow[t]{3}{*}{ BCA, GNP, GRECPT } & 0 & 16.02 & 11.14 & 19.40 & 14.41 & 32.02 & 26.60 & 30.33 & 21.31 \\
\hline & 1 & 4.88 & 3.63 & 4.99 & 3.94 & 5.42 & 4.66 & 9.02 & 8.15 \\
\hline & 2 & 1.25 & 1.25 & 1.049 & 1.049 & 0.75 & 0.75 & 0.86 & 0.86 \\
\hline \multirow[t]{3}{*}{ BCA, GNP, GNS } & 0 & 11.29 & 6.87 & 21.46 & 16.34 & 28.46 & 22.51 & 26.46 & 17.39 \\
\hline & 1 & 4.42 & 3.64 & 5.11 & 4.36 & 5.94 & 5.38 & 9.06 & 8.20 \\
\hline & 2 & 0.77 & 0.77 & 0.75 & 0.75 & 0.56 & 0.56 & 0.85 & 0.85 \\
\hline BCA, GNP, & 0 & 25.58 & 19.21 & 16.77 & 10.64 & 25.10 & 19.15 & 22.32 & 13.46 \\
\hline \multirow[t]{2}{*}{$\mathrm{TB}$} & 1 & 6.37 & 4.52 & 6.13 & 4.35 & 5.95 & 4.85 & 8.86 & 7.33 \\
\hline & 2 & 1.84 & 1.84 & 1.77 & 1.77 & 1.10 & 1.10 & 1.52 & 1.52 \\
\hline \multirow[t]{3}{*}{ BCA, GNP, GBMT } & 0 & 24.14 & 17.14 & 15.93 & 10.58 & 18.19 & 12.96 & 18.69 & 12.04 \\
\hline & 1 & 7.00 & 4.63 & 5.35 & 4.11 & 5.22 & 4.43 & 6.64 & 5.70 \\
\hline & 2 & 2.36 & 2.36 & 1.24 & 1.24 & 0.78 & 0.78 & 0.94 & 0.94 \\
\hline \multirow[t]{3}{*}{ BCA, GNP, GBLT } & 0 & 20.11 & 10.71 & 26.81 & 18.90 & 21.82 & 14.97 & 22.81 & 13.10 \\
\hline & 1 & 9.39 & 7.06 & 7.91 & 7.18 & 6.85 & 6.03 & 9.71 & 8.68 \\
\hline & 2 & 2.33 & 2.33 & 0.72 & 0.72 & 0.81 & 0.81 & 1.03 & 1.03 \\
\hline
\end{tabular}

** denotes significance at the $1 \%$ level, $*$ denotes significance at the $5 \%$ level 
Table 8: Johansen-Juselius Multivariate Cointegration Results

\begin{tabular}{|c|c|c|c|c|c|c|c|c|c|}
\hline \multirow{2}{*}{$\begin{array}{l}\text { Variables in } \\
\text { cointegrating } \\
\text { vector }\end{array}$} & \multirow{2}{*}{$\begin{array}{l}\mathrm{R} \\
\mathrm{a} \\
\mathrm{n} \\
\mathrm{k}\end{array}$} & \multirow{2}{*}{\begin{tabular}{|l|} 
Trace \\
Lag 2 \\
\end{tabular}} & \multirow{2}{*}{$\begin{array}{l}\text { Max } \\
\text { Lag } 2\end{array}$} & \multirow{2}{*}{$\begin{array}{l}\text { Trace } \\
\text { Lag } 4\end{array}$} & \multirow{2}{*}{$\begin{array}{l}\operatorname{Max} \\
\operatorname{Lag} 4\end{array}$} & \multirow{2}{*}{$\begin{array}{l}\text { Trace } \\
\text { Lag } 6\end{array}$} & \multirow{2}{*}{$\begin{array}{l}\text { Max } \\
\text { Lag } 6\end{array}$} & \multirow{2}{*}{$\begin{array}{l}\text { Trace } \\
\text { Lag } 8\end{array}$} & \multirow{2}{*}{$\begin{array}{l}\text { Max } \\
\text { Lag } 8\end{array}$} \\
\hline & & & & & & & & & \\
\hline GNP, & 0 & 39.82 & 22.08 & 51.43 & 29.6 & $63.12 * *$ & 28.68 & $84.56^{* *}$ & $43.03 * *$ \\
\hline M2, & 1 & 17.73 & 8.54 & 21.76 & 10.9 & 34.44 & 18.57 & $41.52^{* *}$ & 18.50 \\
\hline \multirow[t]{2}{*}{ TOT } & 2 & 9.19 & 7.16 & 10.82 & 8.53 & 15.87 & 10.89 & $23.01^{*}$ & 16.33 \\
\hline & 3 & 2.024 & 2.024 & 2.29 & 2.29 & $4.98^{*}$ & $4.98^{*}$ & $6.67 * *$ & $6.67 * *$ \\
\hline GNP, & 0 & $61.9 * *$ & $38.31^{* *}$ & 49.39 & 23.3 & 47.79 & 22.84 & $62.09 * *$ & $35.78 * *$ \\
\hline M2, & 1 & 23.65 & 14.68 & 26.02 & 19.1 & 24.94 & 16.42 & 26.30 & 19.08 \\
\hline \multirow[t]{2}{*}{ NEX } & 2 & 8.96 & 5.40 & 6.83 & 5.33 & 8.51 & 5.49 & 7.22 & 4.67 \\
\hline & 3 & 3.56 & 3.56 & 1.50 & 1.50 & 3.02 & 3.02 & 2.544 & 2.54 \\
\hline GNP, & 0 & $51.6^{* *}$ & $31.71 *$ & $55.87 *$ & 27.9 & $56.17 *$ & 26.57 & $71.23^{* *}$ & $32.60^{*}$ \\
\hline \multirow[t]{3}{*}{ M2, GEXP } & 1 & 19.92 & 13.84 & 27.95 & 18.1 & 29.59 & 18.69 & $38.63^{*}$ & $26.04^{*}$ \\
\hline & 2 & 6.08 & 5.90 & 9.82 & 5.33 & 10.89 & 6.37 & 12.58 & 9.74 \\
\hline & 3 & 0.17 & 0.17 & $4.49^{*}$ & $4.4^{*}$ & $4.51^{*}$ & $4.51 *$ & 2.84 & 2.84 \\
\hline GNP, & 0 & 53.35 & $37.68^{* *}$ & 38.25 & 21.0 & $58.06^{*}$ & $36.85^{* *}$ & $55.04 *$ & 25.60 \\
\hline \multirow[t]{3}{*}{ M2, GRECPT } & 1 & 15.67 & 10.51 & 17.18 & 10.5 & 21.21 & 13.96 & 29.43 & 17.54 \\
\hline & 2 & 5.15 & 4.32 & 6.63 & 5.76 & 7.25 & 5.70 & 11.89 & 8.38 \\
\hline & 3 & 0.82 & 0.82 & 0.87 & 0.87 & 1.54 & 1.54 & 3.50 & 3.50 \\
\hline BOT, & 0 & 43.88 & 24.73 & 50.08 & 24.5 & $60.27 *$ & 29.66 & $88.28 * *$ & $54.85 * *$ \\
\hline M2, & 1 & 19.15 & 13.58 & 25.53 & 19.5 & 30.61 & 18.31 & 33.43 & 17.58 \\
\hline \multirow[t]{2}{*}{ TB } & 2 & 5.57 & 5.12 & 5.95 & 5.19 & 12.29 & 11.72 & 15.84 & 13.77 \\
\hline & 3 & 0.44 & 0.44 & 0.75 & 0.75 & 0.57 & 0.57 & 2.07 & 2.07 \\
\hline GNP, & 0 & 47.46 & 28.17 & 53.65 & 24.9 & $59.69^{*}$ & $33.76^{*}$ & $72.86^{* *}$ & $43.97 * *$ \\
\hline \multirow[t]{3}{*}{ M2, GBMT } & 1 & 19.28 & 13.64 & 28.67 & 22.70 & 25.93 & 16.95 & 28.89 & 18.11 \\
\hline & 2 & 5.64 & 5.26 & 5.96 & 5.67 & 8.97 & 7.97 & 10.77 & 8.66 \\
\hline & 3 & 0.38 & 0.38 & 0.28 & 0.28 & 1.00 & 1.00 & 2.10 & 2.10 \\
\hline BOT, GNP, & 0 & 43.81 & 22.58 & $60.20 *$ & 26.9 & $56.25^{*}$ & 25.76 & 83.59 ** & $41.15^{* *}$ \\
\hline \multirow[t]{3}{*}{ M2, GBLT } & 1 & 21.22 & 13.92 & 33.23 & 24.0 & 30.49 & 21.20 & $42.44 * *$ & $24.64 *$ \\
\hline & 2 & 7.30 & 6.87 & 9.14 & 8.73 & 9.29 & 7.79 & 17.79 & 14.73 \\
\hline & 3 & 0.42 & 0.42 & 0.41 & 0.41 & 1.50 & 1.50 & 3.05 & 3.05 \\
\hline
\end{tabular}

** denotes significance at the $1 \%$ level, $*$ denotes significance at the $5 \%$ level 
Table 9: Johansen-Juselius Multivariate Cointegration Results

\begin{tabular}{|c|c|c|c|c|c|c|c|c|c|}
\hline \multirow{2}{*}{$\begin{array}{l}\text { Variables in } \\
\text { cointegrati } \\
\text { ng vector }\end{array}$} & \multirow{2}{*}{$\begin{array}{l}\mathrm{R} \\
\mathrm{a} \\
\mathrm{n} \\
\mathrm{k}\end{array}$} & \multirow{2}{*}{\begin{tabular}{|l|} 
Trace \\
Lag 2 \\
\end{tabular}} & \multirow{2}{*}{$\begin{array}{l}\text { Max } \\
\text { Lag } 2\end{array}$} & \multirow{2}{*}{$\begin{array}{l}\text { Trace } \\
\text { Lag } 4\end{array}$} & \multirow{2}{*}{$\begin{array}{l}\text { Max } \\
\text { Lag } 4\end{array}$} & \multirow{2}{*}{$\begin{array}{l}\text { Trace } \\
\text { Lag } 6\end{array}$} & \multirow{2}{*}{$\begin{array}{l}\text { Max } \\
\text { Lag } 6\end{array}$} & \multirow{2}{*}{$\begin{array}{l}\text { Trace } \\
\text { Lag } 8\end{array}$} & \multirow{2}{*}{$\begin{array}{l}\text { Max } \\
\text { Lag } 8\end{array}$} \\
\hline & & & & & & & & & \\
\hline BCA GNP & 0 & 40.49 & 21.49 & 48.07 & 23.87 & $54.95^{*}$ & 26.18 & $78.86^{* *}$ & $42.00 * *$ \\
\hline M2 & 1 & 19.00 & 9.60 & 23.42 & 12.46 & 28.77 & 12.90 & $36.86^{*}$ & 19.15 \\
\hline \multirow[t]{2}{*}{ TOT } & 2 & 9.39 & 6.11 & 10.94 & 5.63 & 15.87 & 9.13 & 17.71 & 9.59 \\
\hline & 3 & 3.27 & 3.27 & 5.14 & 2.25 & $6.73 * *$ & $6.73 *$ & 8.11 & 8.11 \\
\hline BCA & 0 & $70.85^{* *}$ & $43.05 * *$ & $60.29 *$ & $32.20 *$ & $55.36^{*}$ & 24.81 & $66.46^{* *}$ & $35.22 *$ \\
\hline GNP & 1 & 27.79 & 17.68 & 28.08 & 18.30 & 30.55 & 19.17 & 31.23 & 18.73 \\
\hline M2 & 2 & 10.10 & 7.41 & 9.78 & 8.11 & 11.37 & 9.70 & 12.50 & 10.88 \\
\hline NEX & 3 & 2.68 & 2.68 & 1.67 & 1.67 & 1.67 & 1.67 & 1.62 & 1.62 \\
\hline BCA & 0 & 50.08 & 26.57 & 53.31 & 24.08 & 53.33 & 24.87 & $73.91 * *$ & $32.16^{*}$ \\
\hline GNP & 1 & 23.50 & 17.09 & 29.23 & 21.26 & 28.45 & 19.44 & $41.74 * *$ & $26.91 *$ \\
\hline \multirow[t]{2}{*}{ M2 GEXP } & 2 & 6.41 & 6.41 & 7.96 & 6.12 & 9.00 & 6.40 & 14.83 & 12.17 \\
\hline & 3 & 0.00 & 0.00 & 1.83 & 1.83 & 2.59 & 2.59 & 2.65 & 2.65 \\
\hline BCA GNP & 0 & 45.01 & $32.08^{*}$ & 43.74 & 26.96 & $59.02 *$ & $37.91 * *$ & $56.43^{*}$ & 27.74 \\
\hline M2 & 1 & 12.92 & 8.33 & 16.78 & 9.31 & 21.10 & 12.90 & 28.69 & 15.86 \\
\hline \multirow[t]{2}{*}{ GRECPT } & 2 & 4.59 & 3.22 & 7.46 & 6.61 & 8.20 & 7.44 & 12.83 & 11.28 \\
\hline & 3 & 1.37 & 1.37 & 0.85 & 0.85 & 0.76 & 0.76 & 1.55 & 1.55 \\
\hline BCA GNP & 0 & 43.77 & 21.04 & 46.92 & 26.07 & $56.04 *$ & 26.88 & $88.02 * *$ & $58.05 * *$ \\
\hline M2 & 1 & 22.72 & 16.95 & 20.84 & 13.65 & 29.15 & 20.58 & 29.97 & 16.39 \\
\hline \multirow[t]{2}{*}{$\mathrm{TB}$} & 2 & 5.77 & 3.81 & 7.19 & 3.71 & 8.57 & 6.61 & 13.57 & 9.76 \\
\hline & 3 & 1.95 & 1.95 & 3.48 & 3.48 & 1.95 & 1.95 & 3.80 & 3.80 \\
\hline BCA & 0 & 42.48 & 20.01 & 48.41 & 25.56 & 56.38* & 30.11 & 71.13 ** & $45.87 * *$ \\
\hline GNP & 1 & 22.47 & 16.29 & 22.84 & 16.53 & 26.26 & 18.93 & 25.26 & 16.44 \\
\hline \multirow[t]{2}{*}{ M2 GBMT } & 2 & 6.17 & 4.24 & 6.30 & 4.12 & 7.32 & 5.34 & 8.81 & 6.02 \\
\hline & 3 & 1.92 & 1.92 & 2.18 & 2.18 & 1.98 & 1.98 & 2.79 & 2.79 \\
\hline BCA GNP & 0 & 41.32 & 20.43 & $57.70 *$ & 27.04 & 54.14 & 26.92 & $75.81 * *$ & $41.17 * *$ \\
\hline \multirow[t]{3}{*}{ M2 GBLT } & 1 & 20.88 & 12.33 & 30.66 & 21.10 & 27.21 & 18.47 & $34.63 *$ & 17.71 \\
\hline & 2 & 8.55 & 6.98 & 9.56 & 7.96 & 8.74 & 6.68 & 16.91 & 13.46 \\
\hline & 3 & 1.56 & 1.56 & 1.59 & 1.59 & 2.06 & 2.06 & 3.45 & 3.45 \\
\hline
\end{tabular}

** denotes significance at the $1 \%$ level, * denotes significance at the $5 \%$ level

\section{Conclusion}

In this paper I revisit the long-run determinants of the U.S. external account balances. Previous studies have established that the fiscal, monetary, and commercial policy measures are cointegrated with the U.S. external account balances. To the best of my knowledge, none of these studies have established the interest rate measures to be cointegrated with the external account balances. The primary reason behind leaving the interest rate measures might have been the premise that changes in money supply will take care of the interest rate 
in the desired fashion.

Based on an expanded sample, not only I confirm the findings of the previous studies, but also provide strong evidence to show that the various interest rate measures are also cointegrated with the U.S. external account balances. This finding has important policy implications, because in order to tackle the problem of trade deficit, on the monetary policy side the use of monetary aggregates alone is not sufficient, as it might not influence the interest rate as desired by the Fed due to the money multiplier not realizing its full potential, especially in a recessionary environment where the commercial banks are unwilling to lend funds to the public.

This paper relies on the cointegration tests to determine the long-run relationships among several variables. Studies that use cointegration tests do suffer from some weaknesses. The primary weakness is that the cointegrating vector may not remain constant over the time span used in this study, which violates the assumption of constant cointegrating vectors. This violation may be due to such factors as technological change, natural calamities, changing political environment, etc. This shift in the cointegrating vector will make the long-run relationship uncertain.

\section{References}

Alse, J., \& Bahmani-Oskooee, M. (1992). Are the Twin Deficits Really Related?: A Comment. $\begin{array}{llll}\text { Contemporary } \quad \text { Economic } & \text { Policy, } & 108-11 .\end{array}$ http://dx.doi.org/10.1111/j.1465-7287.1992.tb00218.x

Bahmani-Oskooee, M. (1989). Effects of the U.S. Government Budget on its Current Account: An Empirical Enquiry. Quarterly Review of Economics and Business, 29. 76-91.

Bahmani-Oskooee, M. (1992). What are the Long Run Determinants of the U.S. Trade Balance? Journal of Post Keynesian Economics, 15. 85-97. http://www.jstor.org/pss/4538326

Bahmani-Oskooee, M. (1995). The Long Run Determinants of the U.S. Trade Balance Revisited. Journal of Post Keynesian Economics, $17 . \quad 457-465$. http://www.jstor.org/stable/4538455

Daratt, A.F. (1988). Have Large Budget Deficits Caused Rising Trade Deficits? Southern Economic Journal, 54. 879-887. http://dx.doi.org/10.2307/1059523

Engle, R.F., \& Granger, C.W.J. (1987). Co-integration and Error Correction: Representation, Estimation, and Testing. Econometrica. 55. 251-276. http://dx.doi.org/10.2307/1913236

Granger, C.W.J., \& Newbold, P. (1974). Spurious Regressions in Econometrics. Journal of Econometrics, 2. 111-120. http://dx.doi.org/10.1016/0304-4076(74)90034-7

Johansen, S. (1988). Statistical Analysis of Cointegration Vectors. Journal of Economic $\begin{array}{llll}\text { Dynamics } \quad \text { and } & \text { Control, } & 12 .\end{array}$ http://dx.doi.org/10.1111/j.1468-0084.1990.mp52002003.x

Johansen, S., \& Juselius, K. (1990). Maximum Likelihood Estimation and Inference on 


\section{Macrothink}

Cointegration - With Applications to the Demand for Money. Oxford Bulletin of Economics and Statistics, 52. 169-210. http://dx.doi.org/10.1111/j.1468-0084.1990.mp52002003.x

Kim, K.H. (1995). On the Long-Run Determinants of the U.S. Trade Balance: A Comment. Journal of Post Keynesian Economics, 17(3). 447-455. http://www.jstor.org/stable/4538454

Krugman, P.R., \& Baldwin, R.E. (1987). The Persistence of the U.S. Trade Deficit. Brookings Papers on Economic Activity, 1987. 1. 1-55. http://dx.doi.org/10.2307/2534513

Magee, S.P. (1973). Currency Contracts, Pass Through and Devaluation. Brookings Papers on Economic Activity, 1973. 1. 303-325. http://dx.doi.org/10.2307/2534091

Miller, S.M., \& Russek, F.S. (1989). Are the Twin Deficits Really Related? Contemporary Economic Policy, 7. 91-115. http://dx.doi.org/10.1111/j.1465-7287.1989.tb00577.x

Perron, P. (1989). The Great Crash, The Oil Price Shock, and the Unit Root Hypothesis. Econometrica, 57. 1361-401. http://dx.doi.org/10.2307/1913712

Perron, P. (1990). Testing for a Unit Root in a Time Series with a Changing Mean. Journal of Business and Economic Statistics, 8. 153-62. http://dx.doi.org/10.2307/1391977

Rosensweig, J.A., \& Koch, P.D. (1988). The U.S. Dollar and the Delayed J-Curve. Economic Review. Federal Reserve Bank of Atlanta. 2-15.

\section{Copyright Disclaimer}

Copyright reserved by the author(s).

This article is an open-access article distributed under the terms and conditions of the Creative Commons Attribution license (http://creativecommons.org/licenses/by/3.0/). 